\title{
DEVELOPMENT OF ANTIBACTERIAL MTCU/PLA NANOCOMPOSITES BY CASTING METHOD FOR POTENTIAL USE IN FOOD PACKAGING
}

\author{
J. E. BRUNA*, H. QUILODRÁN, A. GUARDA, F. RODRÍGUEZ, M. J. GALOTTO AND P. FIGUEROA
}

\author{
Food Packaging Laboratory (Laben-Chile), Department of Science and Food Technology, Faculty of Technology, Center for the Development of Nanoscience \\ and Nanotechnology (CEDENNA), University of Santiago de Chile (USACH), Santiago, Chile
}

\begin{abstract}
Polylactic acid (PLA) nanocomposites with two antimicrobial agents based on copper modified montmorillonite $\left(\mathrm{MtCu}^{2+}\right.$ and $\left.\mathrm{MtCu}^{0}\right)$ were developed in order to obtain a lower environmental impact material with antimicrobial activity for potential use in food packaging. Clay modification was permorfed by cation exchange between $\mathrm{MtNa}^{+}$and a copper salt obtaining $\mathrm{MtCu}^{2+}$ and its followed reduction with $\mathrm{NaBH}_{4}$ obtaining $\mathrm{MtCu}^{0}$. Then PLA nanocomposite films $\left(\mathrm{MtCu}^{2+}\right.$ PLA and $\left.\mathrm{MtCu}^{0} / \mathrm{PLA}\right)$, using different concentration of $\mathrm{MtCu}^{2+}$ and $\mathrm{MtCu}^{0}(1,3$ and $5 \mathrm{wt} \%$ ) were obtained by casting technique. X-ray diffraction (XRD) and Transmission electronic microscopy (TEM) analysis evidenced a certain degree of intercalation of the modified clays in the nanocomposites. Thermal, mechanical and optical properties showed variations by incorporating $\mathrm{MtCu}^{2+}$ and $\mathrm{MtCu}^{0}$ in the polymer matrix. On the other hand, it was possible to evidence antimicrobial activity of the nanocomposites (ASTM Standard E2149) against to Escherichia coli ATCC 25922 and Listeria innocua ATCC 33090 obtaining a 99\% maximum of reduction to both bacteria.
\end{abstract}

\section{INTRODUCTION}

The choice of the best material to be used in food packaging is essential to maintain the benefits of quality, safety and security offered by the technologies of preservation, until the packaged food reaches the final consumer'. The materials traditionally used as food packaging are glass, paper or cardboard, metal and plastic ${ }^{2}$, being this last the most used due to its wide availability and its relatively low cost of production, as well as, its good mechanical performance such as tensile strength, gas barrier ${ }^{3}$, flexibility, lightness ${ }^{4}$ and versatility ${ }^{5}$. However, large quantity of these types of materials comes from non-renewable sources being also non-biodegradable materials, causing a negative impact to the environment because once these are discarded they become a great source of waste generation and accumulation, polluting diverse ecosystems ${ }^{6}$.

An alternative to this problem is the use of biodegradable polymers, which under specific environmental conditions and the presence of microorganisms, are degraded by chemical processes which produce water, carbon and compost ${ }^{3}$.

Recently, various investigations have focused on the applicability of biobased biodegradable polymers in food packaging, such as the use of starch derivatives with polyester ${ }^{7}$, cellulose ${ }^{8}$, casein ${ }^{9}$, soy protein isolat ${ }^{10}$, polylactic acid/Chitosan ${ }^{11}$ and polylactic acid/starch ${ }^{12}$. Among these polymers, biodegradable polylactic acid (PLA) is a versatile biodegradable polymer which can be used in various industrial sectors such as the automotive and biomedical, as well as food packaging ${ }^{13-15}$. The significant potential for the food packaging industry is due to the high transparency and rigidity, excellent printability and processability ${ }^{15}$, making use of PLA for various promising enduse applications ${ }^{16}$. PLA at industrial level is synthesized from lactic acid via lactide formation, because it allows to obtain high molecular weight polymer ${ }^{17}$. A major advantage of this polymer is that it can be processed by the same techniques used for conventional polymers, such as melt extrusion, injection molding, blow molding, thermoforming, and film formation by solvent dilution. Moreover, it should be noted that this material is recognized by the FDA as a GRAS substance and permitted as a food packaging material (FDA, PB-283 713/6).

In this way, it has had many uses in food packaging such as: cups, plates, trays, clamshell containers and disposable boxes for direct consumer products and short shelf life. It has also been reported its use for laboratory containers with vegetables and bakery products, tea bags and water bottles, milk, yogurt, vegetable oil and fruit juices ${ }^{17}$. Despite the fact that their use is becoming increasingly popular, it can be limited to certain types of products, because some of the polymer properties need to be improved for specific applications, such as the high permeability to gases and vapors as well as poor mechanical and thermal properties ${ }^{18}$. Despite all the efforts made so far to improve the deficiencies of PLA, no results have been achieved which allows this type of polymers to replace traditional polymers (about their properties). In this sense, nanotechnology is emerging as a real alternative to minimize the deficiencies of this group of properties, for its high performance and also by the low concentrations used and prices ${ }^{17}$. Thus, various types of nanoparticles are being used in order to improve the properties of these materials: spherical or cubic, tubular and lamellar nanoparticles ${ }^{19}$. More attention has been focused to lamellar solids, such as clays and silicates, due to their availability, low cost, significant improvements and relatively simple processability ${ }^{20}$. Among the clays, one of the most studied has been the montmorillonite (Mt) which is formed by sheets with an inner layer octahedral layer sandwiched between two tetrahedral silicate ${ }^{21}$, There is a space between the layers called interlaminar region which has a negative charge, where sodium ions are typically located ${ }^{22}$. So clays can be modified by cation interchange process with a large number of ions obtaining new functional materials ${ }^{23}$.

Moreover, it has been found that the incorporation of the polymeric matrix Mt can decrease the permeability of the material, resulting in a material with good barrier properties. This effect has been explained due to the tortuous path created by the clay particles ${ }^{24}$, because the filler materials are essentially impermeable inorganic crystals, gas molecules must diffuse around them rather than taking a straight line path that lies perpendicular to the film surface ${ }^{25}$.

Traditionally, food packaging has been defined as a passive barrier which protects and retards the effects on food caused by the external environment ${ }^{26}$. However, due to consumer demand for minimally processed foods, as well as the need to extend the shelf life and quality of packaged foods. Have been developed the so-called active and intelligent packaging, which are based on intentional interaction with food or the environment that surrounds the food ${ }^{27}$,

in order to meet these needs. One of the active packaging most studied are those with antimicrobial activity, which can eliminated or inhibited the growth of microorganisms. As antimicrobial agents there have been reported: organic acids, peptides, enzymes, antibiotics, bacteriocins and metals ${ }^{28}$, the latter being those who have drawn more attention for its broad action range. In this regard, the addition of metals in polymer matrix either in the salts, oxides, complexes and colloids form, metals are one of the most interesting and promisors additive to produce active packaging ${ }^{29}$.

Copper is one of the most abundant metals in nature, found in the oxides, sulfides, carbonates, sulfates and chlorides forms. This metal has antimicrobial activity and is highly toxic to bacterial cells ${ }^{30}$, being observed that copper has a higher efficiency to temperature and humidity levels typical of indoor environments, than silver. This property has favored the use of copper as antimicrobial materials in indoor environments such as hospitals ${ }^{31}$. Thus, Grass and coworkers have described a series of events that cause the death of microorganisms by direct contact with copper surface ${ }^{32}$. Copper has a highly active redox potential, allowing it to accept or donate electrons easily (Nan y col., 2008). This property allows it to generate various chemical species with antimicrobial activity, such as $\mathrm{Cu}^{1+}, \mathrm{Cu}^{2+33}, \mathrm{CuO}^{34}$ and $\mathrm{Cu}_{2} \mathrm{O}^{35}$, with the most powerful species known antimicrobial ionic $\mathrm{Cu}^{2+32}$. In the last study, the use of copper in metallic state $\left(\mathrm{Cu}^{0}\right)$ was studied, because it is a highly reactive species that can produce all antimicrobial species listed above, thereby causing bacterial death ${ }^{33,36}$.

Copper antimicrobial activity has been confirmed over a broad spectrum of microorganisms such as Escherichia coli O157:H7, Staphylococcus aureus, Enterobacter aerogenes, Pseudomona aeruginosa ${ }^{29}$, Listeria monocytogenes ${ }^{37}$, Salmonella entérica, Campylobacter jejuni ${ }^{38}$, Klebsiella pneumoniae, Mycobacterium tuberculosis, Candida albicans ${ }^{39}$, Clostridium difficile $^{40}$, Aspergillus flavus, Aspergillus niger, Penicillium chrysogenum ${ }^{41}$ Saccharomyces cereviciae ${ }^{42}$. 
In the present work, modified montmorillonites $\left(\mathrm{MtCu}^{2+}\right.$ and $\left.\mathrm{MtCu}^{0}\right)$ were prepared to be used as active agents in PLA nanocomposite films. The nanocomposites elaborated were characterized by opacity index, X-Ray diffraction (XRD), tensile test, differential scanning calorimetry (DSC) transmission electron microscopy ${ }^{43}$ and antimicrobial activity against $E$. coli and L. innocua .

\section{EXPERIMENTAL}

\subsection{Materials}

Polylactic Acid (Melt flow index: $6 \mathrm{dg} / \mathrm{min}$ at $210{ }^{\circ} \mathrm{C} / 2.16 \mathrm{Kg}, 4$ wt. $\%$ d-isomer), Nature Works LLC (Ingeo ${ }^{\mathrm{TM}}$ Biopolymer 2003D); Cloisite $\AA$ $\mathrm{Na}^{+}$, was purchased from Southern Clay Products, Inc., Na-Montmorillonite $\left(\mathrm{MtNa}^{+}\right)$; Cupric sulfate pentahydrate $\left(\mathrm{CuSO}_{4} \times 5 \mathrm{H}_{2} \mathrm{O}\right), 99.995 \%$ trace metals, Aldrich; Sodium borohydride, powder, $98 \%$, Aldrich, Poly(ethylene Glycol) (PEG) as plasticizer, Number Average Molecular Weight: 400, were pursached in Aldrich. Luria-Bertani medium for bacteria were used in this study. Escherichia coli (ATCC 25922) obtained from the Public Health Institute, ISP (Santiago, Chile) and Listeria innocua (ATCC 33090) obtained from MedicaTec (Santiago, Chile).

\subsection{Modified Clays preparation}

\subsection{1 $\mathrm{MtCu}^{2+}$}

$\mathrm{MtNa}^{+}$was modified in solution by ion interchange with a $\mathrm{CuSO}$ solution For this purpose, a $\mathrm{MtNa}^{+}$suspension and $\mathrm{CuSO}_{4}$ solution were mixed at $60^{\circ} \mathrm{C}$, during 3 hours with stirring. At the end of reaction the product was centrifuged at $4000 \mathrm{rpm}$ and the sediment was washed with distilled water three times. The product was dried at $80^{\circ} \mathrm{C}$ over night and ground in a mortar to obtain a material under 270 mesh. The supernatant was diluted properly and then the copper concentration was measured using an atomic absorption spectrophotometer. So, the content of copper into the modified clay was estimated ${ }^{44}$.

\subsection{2. $\mathrm{MtCu}^{0}$}

The $\mathrm{MtCu}^{2+}$ obtained in 2.2.1 was suspended in distilled water and a $\mathrm{NaBH}_{4}$ solution $(0.1 \mathrm{M})$ was then added, as a reducing agent, under continuous stirring at $40{ }^{\circ} \mathrm{C}$. Later, $\mathrm{MtCu}^{0}$ suspensions were centrifuged at $4000 \mathrm{rpm}$ and washed several times with a 50:50 etanol/water solutions to remove residual reactants. Finally the product was dried at $40{ }^{\circ} \mathrm{C}$ for 3 days in oven and ground in a mortar to sizes less than 270 mesh $(<45 \mu \mathrm{m})^{45}$.

\subsection{Nanocomposites preparation}

$\mathrm{MtCu} / \mathrm{PLA}$ nanocomposites were prepared in three different compositions $(1,3$ and $5 \mathrm{wt} . \% \mathrm{MtCu})$ by casting technique. First, the required amounts of PLA and PEG (10 wt.\%) were dissolved in $\mathrm{CH}_{3} \mathrm{Cl}$ under vigorous stirring for 2 hours at ambient temperature. In parallel, the determined amounts of $\mathrm{MtCu}$ were suspended in chloroform and sonicated for 20 minutes at room temperature. After this time, $\mathrm{MtCu}$ suspensions were added on solution (PLA+PEG) and were subjected to stirring for 20 minutes. Subsequently obtained mixtures were sonicated for 20 minutes at room temperature. Finally the mixtures were deposited on Petri dishes $\left(20 \mathrm{~cm}\right.$ in diameter), drying at $40{ }^{\circ} \mathrm{C}$ for $2 \mathrm{~h}$ and further dried at $40{ }^{\circ} \mathrm{C}$ in a vacuum oven to remove the remaining solvent ${ }^{46}$, obtaining films of about $90 \mu \mathrm{m}$ of thickness.

\subsection{Characterization \\ 2.4.1. Optical Properties \\ 2.4.1.1. Color}

In order to evaluate the color changes produced by the addition of the modified clays in the films obtained, color parameters were evaluated. For this, the samples were analyzed on a Minolta colorimeter CR-410 Chroma Meter (Minolta Series, Tokio, Japan), using the CIELab scale, obtaining the parameter of brightness $\left(\mathrm{L}^{*}\right)$ and chromaticity $\left(\mathrm{a}^{*}\right.$ and $\mathrm{b} *$ ). As background it was used the standard white plaque $\left(L^{*}=97.11, a^{*}=-0.03\right.$ and $\left.b^{*}=1.96\right)$, with a D65 illuminant and $2^{\circ}$ observer. Also color differences $(\Delta \mathrm{E})$ and Whitish Index were calculated from the obtained parameters with respect to the PLA film without nanofiller using equations $\Delta \mathrm{E}=\left[\left(\Delta \mathrm{L}^{*}\right)^{2}+\left(\Delta \mathrm{a}^{*}\right)^{2}+\left(\Delta \mathrm{L}^{*}\right)^{2}\right]^{1 / 2}$ and $\mathrm{Wi}=100-[(100-$ $\left.\left.\mathrm{L}^{*}\right)^{2}+\mathrm{a}^{* 2}+\mathrm{b}^{* 2}\right]^{1 / 2}$, respectively ${ }^{47}$.

\subsubsection{Opacity}

Absorbance measurement was used in order to evaluate changes in the opacity of nanocomposites films. The absorbance values of each film were obtained using a UV/Visible spectrophotometer Spectroquant ${ }^{\circledR}$ Pharo $300 \mathrm{M}$ (Darmstadt, Germany) at a wavelength of $600 \mathrm{~nm}$. The films samples $(1 \times 5 \mathrm{~cm})$ were introduced into the equipment compartment for its measurement. Finally, the opacity of each sample was calculated using Opacity $=\mathrm{Abs}_{600} / \mathrm{X}$, where: $\mathrm{Abs}_{600}=$ Absorbance at $600 \mathrm{~nm} ; \mathrm{X}=$ Film thickness (mm).

\subsubsection{X-Ray Diffraction}

$\mathrm{X}$-ray diffraction (XRD) analysis were conducted on nanocomposite films using a Siemens D5000 (30mA y 40kV) equipment (Munich, Germany) with $\mathrm{X}$-ray source of $\mathrm{CuK} \alpha(\lambda=1,54 \AA)$. Scan rate was $1.2^{\circ} \mathrm{min}^{-1}$ on a diffraction angle $2 \theta$ in a range of 3 to $10^{\circ}$. The results were evaluated according to Bragg's law given by $\sin \theta=\mathrm{n} \lambda / 2 \mathrm{~d}{ }^{48}$, which relates the interlayer distance of the clay with the angle of the incident rays and the scattering planes.

\subsubsection{Transmission electron microscopy}

The nanomorphology of the films was examined by transmission electron microscope. The samples were cut ( 80 to $90 \mathrm{~nm})$ by a Sorvall MT-5000 ultramicrotome and analyzed onto a copper grid 300 mesh by transmission electron microscope Tecnai 12 Bio Twin Phillips (Eindhoven, Holand) with $80 \mathrm{kV}$ accelerating voltage, obtaining micrographs with magnification 43000x, and 60000x.

\subsubsection{Differential scanning calorimetry (DSC)}

DSC analysis were carried out using a Mettler Toledo model DSC 822e differential scanning calorimeter (Greifensee, Switzerland) under a nitrogen atmosphere. Eight milligrams of samples were sealed in aluminum pans and heated from 20 to $200{ }^{\circ} \mathrm{C}$ at a heating rate of $10{ }^{\circ} \mathrm{C} / \mathrm{min}$ and immediately cooled at the same rate to $20^{\circ} \mathrm{C}$. For the second scan, the samples were heated under the same conditions. The glass transition ( $\mathrm{T}$ ) and melting temperatures ${ }^{11}$ were estimated in the second heating scans and cold crystallization $\left(\mathrm{T}_{\mathrm{cc}}\right)$ temperatures with their respective enthalpies $(\Delta \mathrm{H})$ were estimated during the previous cooling scans. The percentage of crystalline fraction $\left(\mathrm{X}_{\mathrm{c}}\right)$ in the films was calculated using $\mathrm{X}_{\mathrm{c}}=\left[\left(\Delta \mathrm{H}_{\mathrm{m}}-\Delta \mathrm{H}_{\mathrm{c}}\right) / 93\right] \times 100$, where 93 is the melting enthalpy of $100 \%$ crystalline PLA in $\mathrm{J} / \mathrm{g}^{49}$.

\subsubsection{Mechanical properties}

Tensile tests were carried out in order to evaluate the behavior of the mechanical properties of nanocomposites films. The analyzes were performed on a Universal Testing Machine Zwick ® Roell BDO-FB model 0.5 TH (Ulm, Germany), in accordance with ASTM D 882 with a crosshead speed of $50 \mathrm{~mm} /$ min. Previously, all samples $(2.5 \times 10 \mathrm{~cm})$ were conditioned at $27^{\circ} \mathrm{C}$ for 48 hours at a relative humidity of $50 \%$.

\subsubsection{Antimicrobial Activity}

The antimicrobial activity of the nanocomposites films was determined under dynamic contact conditions, using a modified ASTM 2149 standard test method. The samples $(0.5 \mathrm{~g})$ were previously sterilized by direct exposure to short-wave ultraviolet radiation (UV-C) and then they were placed in dynamic contact with a fixed concentration of bacterial dilution of $x 10^{7} \mathrm{CFU} / \mathrm{mL}$ in a buffer monobasic potassium phosphate $\left(\mathrm{KH}_{2} \mathrm{PO}_{4}\right) 0.3 \mathrm{mM}$ for 24 hours at $37^{\circ} \mathrm{C}$ and $150 \mathrm{rpm}$ with constant agitation. It is noteworthy that three controls were introduced, the first time to evaluate the initial count (bacterial dilution seeding fixed concentration), the second and the third at 24 hours to assess cell viability (planting tube incubated without film) and calculating the percent inhibition (planting tube with no antimicrobial film), respectively. After the incubation period, serial dilutions were made $\left(10^{-5}\right.$ in controls and $10^{-3}$ in antimicrobial films), where the last 4 dilutions of each set were seeded in LB agar dishes by the technique of micro-droplets. The seeded dishes were incubated at $37^{\circ} \mathrm{C}$ for 16 hours, and then counted the microorganisms. Finally, the antimicrobial activity quantification was based on a logarithmic relationship between the percentage and number of colonies counted after the dynamic contact in the control and antimicrobial films.

\section{RESULTS AND DISCUSSION}

\subsection{Optical Properties}

CIElab Color parameters ( $\mathrm{L}^{*}, \mathrm{a}^{*}$ and $\mathrm{b}^{*}$ ) were obtained by colorimetric analysis in order to evaluate the color differences of films obtained after the addition of modified clays $\left(\mathrm{MtCu}^{2+}\right.$ and $\mathrm{MtCu}^{0}$ ) in the polymer matrix (Table 1). It was possible to observe a reduction in lightness values with increasing $\mathrm{MtCu}^{2+}$ concentration in the polymer matrix, indicating that the nanocomposite film are getting darker. Moreover, $a^{*}$ and $b^{*}$ parameters shown a green and yellow color trend, due to a decrease in $\mathrm{a}^{*}$ and increased in $\mathrm{b}^{*}$ values, when the nanofiller is added in the polymer matrix. A similar behavior was reported by Ataeefard and Moradian ${ }^{50}$ in organoclay/PP nanocomposites studies, where the nanocomposites became yellower by increasing the content of nanoclay. 
Thus, in the results obtained it is possible to observe that the incorporation of $\mathrm{MtCu}^{2+}$ generated slight, but significant, color differences $(\Delta \mathrm{E})$ in the films obtained when compared to the pure PLA. In the same way, it was possible to observe in the Table 1 an increase in the whitish index value by increasing $\mathrm{MtCu}^{2+}$ concentration.

Regarding to $\mathrm{MtCu}^{0} / \mathrm{PLA}$ nanocomposites, it was also possible to observe a decrease in lightness and an increase in the color difference after $\mathrm{MtCu}^{0}$ was added in the polymer matrix, but $\mathrm{L}$ and $\Delta \mathrm{E}$ values were higher in these nanocomposites with visually detectable color differences. This effect may be due to the existence of copper nanoparticles in PLA matrix, which can be explained due to the oxidation of these nanoparticles ${ }^{51}$.

On the other hand, the opacity index of PLA and nanocomposites films was also determinate. It was possible to observe that this parameter was significantly affected after the addition of a $3 \mathrm{wt} . \% \mathrm{MtCu}^{2+}$. This decrease of transparency of the material, it is due to a possible agglomeration of modified clays what prevent the passage of light ${ }^{44}$. In the same way, an increase in the opacity of films is observed when $\mathrm{MtCu}^{0}$ was used as nanofiller, obtaining higher values compared to the $\mathrm{MtCu}^{2+}$ incorporation, which can be attributed to the presence of copper nanoparticles in the polymer matrix.

Table 1. Optical properties of PLA, $\mathrm{MtCu}^{2+} / \mathrm{PLA}$ and $\mathrm{MtCu}^{0} / \mathrm{PLA}$ nanocomposites

\begin{tabular}{|c|c|c|c|c|c|c|}
\hline Sample & $\mathbf{L}^{*}$ & $\mathbf{a}^{*}$ & $\mathbf{b}^{*}$ & $\boldsymbol{\Delta E}$ & Whitish Index & Opacity \\
\hline & & & & & & \\
\hline & $98.1 \pm 0.2^{\mathrm{a}}$ & $-0.14 \pm 0.02^{\mathrm{a}}$ & $2.38 \pm 0.09^{\mathrm{a}}$ & - & & \\
\hline & & & & & & \\
\hline $1 \% \mathrm{MtCu}^{2+} / \mathrm{PLA}$ & $98.1 \pm 0.2^{\mathrm{a}}$ & $-0.39 \pm 0.05^{\mathrm{b}}$ & $2.52 \pm 0.09^{\mathrm{a}}$ & $0.35 \pm 0.10^{\mathrm{a}}$ & $96.9 \pm 0.2^{\mathrm{a}}$ & $2.37 \pm 0.14^{\mathrm{a}}$ \\
\hline $3 \% \mathrm{MtCu}^{2+} / \mathrm{PLA}$ & $97.7 \pm 0.3^{\mathrm{a}}$ & $-0.77 \pm 0.13^{\mathrm{c}}$ & $3.27 \pm 0.24^{\mathrm{b}}$ & $1.20 \pm 0.31^{\mathrm{b}}$ & $95.9 \pm 0.3^{\mathrm{b}}$ & $4.11 \pm 0.34^{\mathrm{b}}$ \\
\hline $5 \% \mathrm{MtCu}^{2+} / \mathrm{PLA}$ & $97.4 \pm 0.3^{\mathrm{a}}$ & $-1,05 \pm 0.10^{\mathrm{d}}$ & $3.71 \pm 0.15^{\mathrm{c}}$ & $1.76 \pm 0.22^{\mathrm{b}}$ & $95.4 \pm 0.2^{\mathrm{b}}$ & $5.73 \pm 0.18^{\mathrm{c}}$ \\
\hline $1 \% \mathrm{MtCu}^{0} / \mathrm{PLA}$ & $95.0 \pm 0.5^{\mathrm{b}}$ & $-1.41 \pm 0.17^{\mathrm{e}}$ & $5.22 \pm 0.46^{\mathrm{d}}$ & $4.38 \pm 0.64^{\mathrm{c}}$ & $92.7 \pm 0.6^{\mathrm{c}}$ & $3.69 \pm 0.27^{\mathrm{a}, \mathrm{b}}$ \\
\hline $3 \% \mathrm{MtCu}^{0} / \mathrm{PLA}$ & $88.5 \pm 1.2^{\mathrm{c}}$ & $-3.23 \pm 0.38^{\mathrm{f}}$ & $10.29 \pm 0.87^{\mathrm{e}}$ & $12.84 \pm 1.50^{\mathrm{d}}$ & $84.3 \pm 1.5^{\mathrm{d}}$ & $6.56 \pm 1.93^{\mathrm{c}}$ \\
\hline $5 \% \mathrm{MtCu}^{0} / \mathrm{PLA}$ & $79.5 \pm 1.7^{\mathrm{d}}$ & $-4.74 \pm 0.25^{\mathrm{g}}$ & $15.43 \pm 0.82^{\mathrm{f}}$ & $23.19 \pm 1.88^{\mathrm{e}}$ & $73.9 \pm 1.9^{\mathrm{e}}$ & $9.87 \pm 2.94^{\mathrm{d}}$ \\
\hline
\end{tabular}

Different letters $(\mathrm{a}-\mathrm{g})$ indicate significant differences among the values of the same optical property.

\subsection{X-ray Diffraction (XRD)}

In order to evaluate the interaction between modificated clays and PLA, XRD patterns of PLA, $\mathrm{MtCu}^{2+}, \mathrm{MtCu}^{0}$ and PLA nanocomposites films were obtained.

Modified clays showed a single peak around $7^{\circ}(2 \theta$ angle) which is shifted to low $2 \theta$ angles when were incorporated in to PLA, indicating an increase of the intercalation distance (Figure 1). In this way, an increase in the interlaminar distance of $\mathrm{MtCu}^{2+}$ from $1.22 \mathrm{~nm}\left(2 \theta=7.21^{\circ}\right)$ to $1.81 \mathrm{~nm}\left(2 \theta=4.88^{\circ}\right)$ was observed in the case of $1 \% \mathrm{MtCu}^{2+} / \mathrm{PLA}$, with a maximum value of $1.79 \mathrm{~nm}$ $\left(2 \theta=4.92^{\circ}\right)$ when 3 and 5 wt. $\%$ of $\mathrm{MtCu}^{2+}$ were added. Likewise, the $\mathrm{MtCu}^{0} \%$ PLA nanocomposites showed an increase in the interlaminar distance of $\mathrm{MtCu}^{0}$ from $1.25 \mathrm{~nm}\left(2 \theta=7.03^{\circ}\right)$ to $1.69 \mathrm{~nm}\left(2 \theta=5.22^{\circ}\right)$ when $1 \mathrm{wt} . \% \mathrm{MtCu}^{0}$ was incorporated and $1.77 \mathrm{~nm}\left(2 \theta=5.00^{\circ}\right)$ with a 3 and $5 \mathrm{wt} . \%$ of $\mathrm{MtCu}^{0}$ were added. In this way, in both types of nanocomposites $\left(\mathrm{MtCu}^{2+} / \mathrm{PLA}\right.$ and $\mathrm{MtCu}^{\circ}$ \% PLA) the clay are in intercalated form in the polymer ${ }^{52}$, being favored by the plasticizer (PEG) present, due to its lower molecular weight which can promotes the mobility and distribution of the polymer chains in the interlaminar space of the clays ${ }^{53}$. Moreover, it should be noted that the distances of the clay interlayer space remain constant, independent of the amount incorporated into the polymer matrix, which it is due to the clay intercalation is related to the interaction between the modified clays and polymeric matrix ${ }^{54}$, and not by the amount added.

\subsection{Transmission Electron Microscopy}

TEM analysis were performed in order to evaluate the behavior of the modified clays in the nanocomposites obtained (Figure 2) using 43,000X and $60,000 \mathrm{X}$ magnifications. In $1 \% \mathrm{MtCu}^{2+} / \mathrm{PLA}$ nanocomposites can be observed that the clays are not well dispersed in the matrix of PLA presenting both tactoids and intercalated structures corroborating the XRD results.

In the case of $1 \% \mathrm{MtCu}^{0} / \mathrm{PLA}$ nanocomposite is possible to observe a poor clay distribution in the polymer matrix, with tactoids structures. Moreover, when the concentration is increased up $5 \mathrm{wt} . \%$, it was possible to observe a decrease in the size of agglomerations, indicating an improvement in the clay dispersion (without varying the intercalation degree), it should be noted that in all cases exfoliated structures were also evidenced.

On the other hand, it was possible to observe in $\mathrm{MtCu}^{0} / \mathrm{PLA}$ nanocomposites (Figure $2 \mathrm{c}$ and $2 \mathrm{~d}$ ) the presence of spherical structures corresponding to metallic copper nanoparticles ${ }^{36}$, which are located outside the structure of the clay. This phenomenon may be due to a displacement of reduced copper, located in the interlaminar space of the clay, at the time of the intercalation of PLA chains is produced. This is favored, because to reduce $\mathrm{Cu}^{2+}$ to $\mathrm{Cu}^{0}$ decreases the attraction with the surface of the interlayer space (negatively charged $)^{55}$, facilitating its released to the polymer matrix.

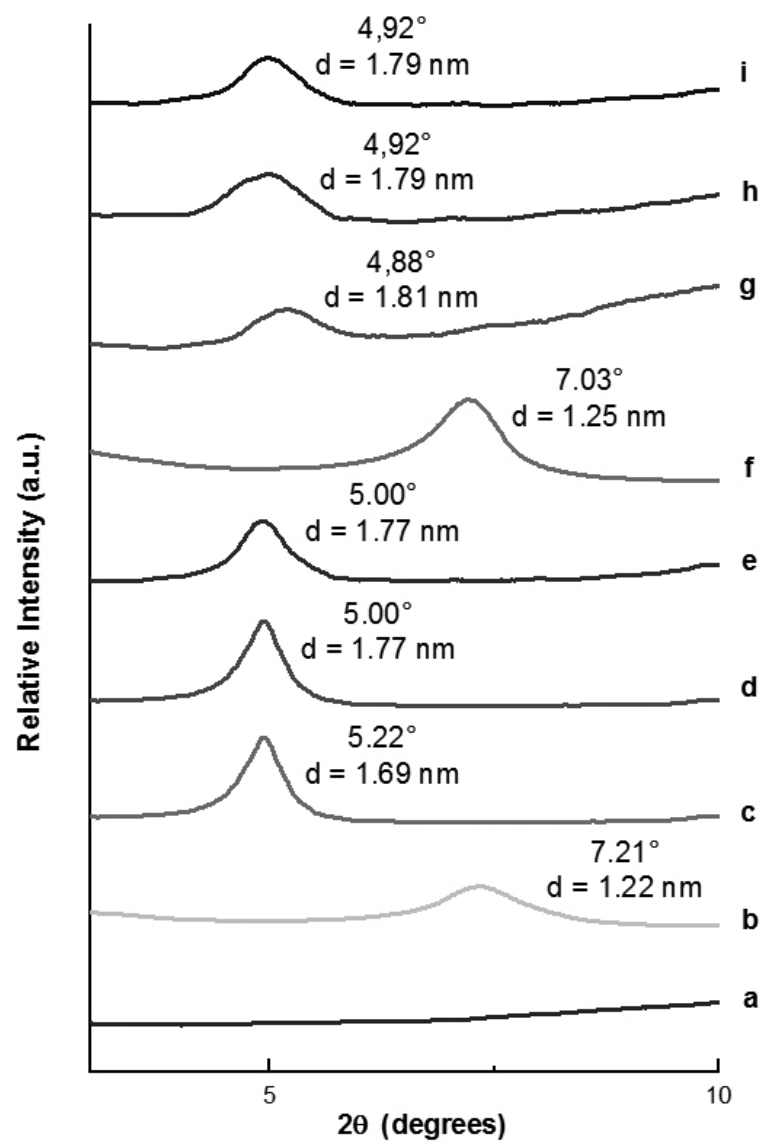

Figure 1. XRD patterns of a) PLA, b) $\mathrm{MtCu}^{0}$ c) $1 \% \mathrm{MtCu}^{0} / \mathrm{PLA}$, d) $3 \% \mathrm{MtCu}^{0} / \mathrm{PLA}$, e) $5 \% \mathrm{MtCu}^{0} / \mathrm{PLA}$, f) $\mathrm{MtCu}^{2+}$, g) $1 \% \mathrm{MtCu}^{2+} / \mathrm{PLA}$, h) $3 \%$ $\mathrm{MtCu}^{2+} / \mathrm{PLA}$, i) $5 \% \mathrm{MtCu}^{2+} / \mathrm{PLA}$. 


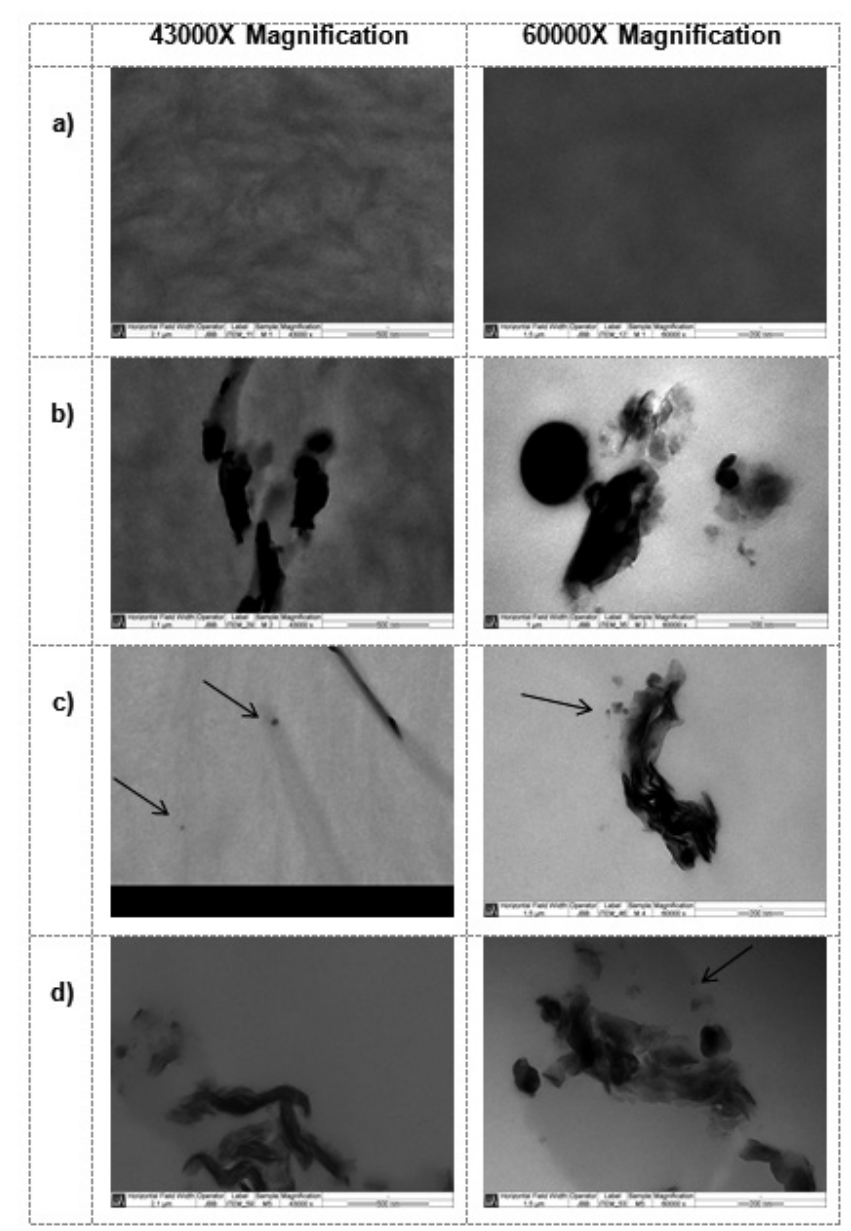

Figure 2. TEM micrographs of: a) PLA, b) $1 \% \mathrm{MtCu}^{2+} / \mathrm{PLA}$ c) $1 \% \mathrm{MtCu}^{0}$ PLA, d) $5 \% \mathrm{MtCu}^{0} / \mathrm{PLA}$ with $43000 \mathrm{x}$ and $60000 \mathrm{x}$ magnification.

\subsection{Thermal properties}

The thermal behavior of the different nanocomposites films was evaluated by DSC, in order to evaluate how the introduction of the modified clays can affect the glass transition $\left(\mathrm{T}_{\mathrm{g}}\right)$, melting $\left(\mathrm{T}_{\mathrm{m}}\right)$ and cold crystallization $\left(\mathrm{T}_{\mathrm{cc}}\right)$ temperatures and crystallization parameters of PLA.

In Table 2, it is possible to observe that $T_{g}$ and $T_{m}$ values of the nanocomposites films were not affected with the presence of modified clay remained practically constant when compared with PLA (independent of nanofiller concentration). However, it is possible to observe changes in the $\mathrm{T}$ values regarding PLA, indicating that the modified clays would affect the crystallization of the polymeric matrix. Thus, by introducing $\mathrm{MtCu}^{2+}$ in the polymer the crystalline content decreased. Moreover, this decrease was greater by increasing the concentration of the modified clay, which can be attributed to the decrease of free available chains polymer in the formation of crystals, resulting in a decrease crystallinity ${ }^{56}$. By contrast, in the case of $\mathrm{MtCu}^{0} / \mathrm{PLA}$ nanocomposites the crystalline fraction percentage increased with increasing concentration of $\mathrm{MtCu}^{0}$ which can be attributed to the presence of copper nanoparticles into polymer matrix.These copper nanoparticles would be acting as nucleating agents that allow mobility and reorganization of other regions of the chains polymer resulting in an increase in the crystallinity ${ }^{57}$. It should be noted that after the addition of $5 \% \mathrm{wt}$. of nanofiller in the polymer matrix, a decrease in crystallinity was observed. Here large amount of clay would be preventing the arrangement and mobility of PLA chains. In addition, the nanoparticles could generate free copper agglomerations affecting the crystallization process.

\subsection{Mechanical properties}

Mechanical properties of the films obtained were evaluated by the elastic modulus, tensile strength and elongation at break. In Table 3 it is possible to observe that the incorporation of modified clays $\left(\mathrm{MtCu}^{2+}\right.$ and $\left.\mathrm{MtCu}^{0}\right)$ increase the elasticity modulus of PLA, because this type of additive would act as reinforcing agents, causing more rigidity to the material ${ }^{58}$. These findings are consistent with previous studies carried out by Balakrishnan et al. ${ }^{16}$ who observed that after the incorporation of montmorillonite, the elastic modulus of PLA increased, due to the Mt constrains the molecular motion of PLA chains, by the existence of hydrogen-bonding interactions between PLA hydroxyl end groups and the Mt platelets surfaces.

Table 2. DSC data of PLA, $\mathrm{MtCu}^{2+} / \mathrm{PLA}$ and $\mathrm{MtCu}^{0} / \mathrm{PLA}$ nanocomposites.

\begin{tabular}{|c|c|c|c|c|c|c|}
\hline Sample & $\begin{array}{c}\mathbf{T g} \\
\left({ }^{\circ} \mathbf{C}\right)\end{array}$ & $\begin{array}{c}\mathbf{T}_{\mathbf{m}} \\
\left({ }^{\circ} \mathbf{C}\right)\end{array}$ & $\begin{array}{c}\Delta \mathbf{H}_{\mathbf{m}} \\
(\mathbf{J} / \mathbf{g})\end{array}$ & $\begin{array}{c}\mathbf{T}_{\mathbf{c}} \\
\left({ }^{\circ} \mathbf{C}\right)\end{array}$ & $\begin{array}{c}\Delta \mathbf{H}_{\mathbf{c}} \\
(\mathbf{J} / \mathbf{g})\end{array}$ & $\begin{array}{c}\mathbf{X}_{\mathbf{c}} \\
(\mathbf{\%})\end{array}$ \\
\hline PLA & 37.8 & 150.4 & 28.0 & 74.6 & 17.5 & 11.3 \\
\hline $1 \% \mathrm{MtCu}^{2+} / \mathrm{PLA}$ & 37.2 & 150.5 & 27.2 & 81.1 & 18.7 & 9.1 \\
\hline $3 \% \mathrm{MtCu}^{2+} / \mathrm{PLA}$ & 40.1 & 151.1 & 20.8 & 86.1 & 16.6 & 4.6 \\
\hline $5 \% \mathrm{MtCu}^{2+} / \mathrm{PLA}$ & 35.3 & 148.4 & 21.5 & 83.2 & 18.6 & 3.2 \\
\hline & & & & & & \\
\hline $1 \% \mathrm{MtCu}^{0} / \mathrm{PLA}$ & 38.0 & 151.9 & 34.1 & 81.4 & 18.2 & 17.1 \\
\hline $3 \% \mathrm{MtCu}^{0} / \mathrm{PLA}$ & 36.9 & 149.5 & 32.4 & 77.4 & 12.8 & 21.2 \\
\hline $5 \% \mathrm{MtCu}^{0} / \mathrm{PLA}$ & 37.3 & 150.2 & 30.8 & 80.9 & 16.6 & 15.3 \\
\hline
\end{tabular}

On the other hand, it is possible to observe that the elastic modulus obtained reaches higher values in $\mathrm{MtCu}^{0} / \mathrm{PLA}$ nanocomposites, which may be attributed not only to the clay presence but to the presence of copper nanoparticles located outside of the montmorillonite structure. This is due to the presence of metal nanoparticles in materials such as PLA, tends to increase the modulus ${ }^{18}$, thus the increase of tensile modulus in the $\mathrm{MtCu}^{0} /$ PLA nanocomposites is produced by a synergistic effect of both free metallic copper nanoparticles and the clay structure. Therefore, a significant decrease was observed of elongation at break when $\mathrm{MtCu}^{2+}$ was added in comparison to PLA. This effect could be due to the restricted slippage of the polymer chains by the presence of the clay ${ }^{53}$. In the case of $\mathrm{MtCu}^{0}$ was not observed a significative change, this may be due to the presence of nano-free copper $\left(\mathrm{Cu}^{0}\right)$ in the polymer matrix (observed by TEM) which maintaining elongation at break values ${ }^{59}$.

Table 3. Mechanical properties of PLA, $\mathrm{MtCu}^{2+} / \mathrm{PLA}$ and $\mathrm{MtCu}^{0} / \mathrm{PLA}$ nanocomposites.

\begin{tabular}{|c|c|c|c|}
\hline Sample & $\begin{array}{c}\text { Tensile } \\
\text { modulus (N/ } \\
\mathbf{m m}^{2} \text { ) }\end{array}$ & $\begin{array}{c}\text { Tensile } \\
\text { strength } \\
\left(\mathbf{N} / \mathbf{m m}^{2}\right)\end{array}$ & $\begin{array}{c}\text { Elongation at } \\
\text { break } \\
(\%)\end{array}$ \\
\hline & & & \\
\hline PLA & $873 \pm 158^{\mathrm{a}}$ & $33.3 \pm 3.6^{\mathrm{a}}$ & $4.16 \pm 0.73^{\mathrm{a}}$ \\
\hline $1 \% \mathrm{MtCu}^{2+} / \mathrm{PLA}$ & $1108 \pm 136^{\mathrm{b}}$ & $30.0 \pm 3.2^{\mathrm{a}}$ & $2.64 \pm 0.42^{\mathrm{b}}$ \\
\hline $3 \% \mathrm{MtCu}^{2+} / \mathrm{PLA}$ & $1136 \pm 118^{\mathrm{b}}$ & $35.5 \pm 1.7^{\mathrm{a}}$ & $3.63 \pm 0.50^{\mathrm{a}}$ \\
\hline $5 \% \mathrm{MtCu}^{2+} / \mathrm{PLA}$ & $1327 \pm 63^{\mathrm{c}}$ & $32.1 \pm 3.3^{\mathrm{a}}$ & $2.85 \pm 0.45^{\mathrm{b}}$ \\
\hline & & & \\
\hline $1 \% \mathrm{MtCu}^{0} / \mathrm{PLA}$ & $1062 \pm 91^{\mathrm{b}}$ & $33.1 \pm 4.9^{\mathrm{a}}$ & $3.32 \pm 0.36^{\mathrm{a}, \mathrm{b}}$ \\
\hline $3 \% \mathrm{MtCu}^{0} / \mathrm{PLA}$ & $1270 \pm 152^{\mathrm{c}}$ & $37.0 \pm 6.6^{\mathrm{a}}$ & $4.37 \pm 0.65^{\mathrm{a}}$ \\
\hline $5 \% \mathrm{MtCu}^{0} / \mathrm{PLA}$ & $1442 \pm 107^{\mathrm{d}}$ & $43.7 \pm 4.7^{\mathrm{b}}$ & $3.84 \pm 0.52^{\mathrm{a}}$ \\
\hline
\end{tabular}

Different letters $(\mathrm{a}-\mathrm{c})$ indicate significant differences among the values of the same mechanical property.

\subsection{Antimicrobial Activity}

The antimicrobial activity of PLA and PLA nanocomposites were evaluated against E. coli ATCC 25922 and L. innocua ATCC 33090. In $\mathrm{MtCu}^{2+} / \mathrm{PLA}$ nanocomposites was possible to reach $5.75 \mathrm{log}$ reduction values corresponding to a $99.99 \%$ of bacterial reduction, while for $\mathrm{MtCu}^{0} / \mathrm{PLA}$ nanocomposites a $1.46 \log$ reduction was achieved corresponding to $99.99 \%$ of $E$. coli reduction 
(Table 4). Moreover, Table 5 shows the results obtained of antimicrobial activity against $L$. Innocua, reaching a value of $2.92 \mathrm{log}$ reduction (99.88\% reduction) in the case of $\mathrm{MtCu}^{2+} / \mathrm{PLA}$ and $5.79 \log$ reduction (99.99\% reduction) in the case of $\mathrm{MtCu}^{0} / \mathrm{PLA}$.

The antimicrobial effect of $\mathrm{MtCu}^{2+} / \mathrm{PLA}$ nanocomposites, would be given by the presence of $\mathrm{Cu}^{2+}$, because these ions have a strong antimicrobial activity removing electrons from the cell walls and cell membranes, thereby causing the output of the cytoplasm and the oxidation of the core cell, with the cell death, to $L$. inocua ${ }^{37}$ and $E$. Coli ${ }^{60}$. Comparing the log reduction values obtained for both types of bacteria, higher values were observed in the case of $E$. coli, than $L$. inосиa which could be explained by the structural difference between the cell wall of these microorganisms. L. innocua has a cell wall composed of a thick layer of peptidoglycan, classifying it as a Gram positive, whereas the $E$. coli has a cell wall composed of a thin peptidoglycan layer and an outer membrane composed of lipopolysaccharides, lipoproteins and phospholipids that generate strong negative charge on their surface. Thus, the interaction of the $\mathrm{Cu}^{2+}$ ions with negatively charged structures, such as $E$. coli, is more susceptible than L.innocua case $^{61}$.

On the other hand, the antimicrobial activity of films $\mathrm{MtCu}^{0} / \mathrm{PLA}$ nanocomposites can be attributed to copper nanoparticles which can be transformed into various chemical species with high antimicrobial activity, such as $\mathrm{Cu}^{+}, \mathrm{Cu}^{2+33}$ and $\mathrm{CuO}^{34}$.

Table 4. Antimicrobial activity of $\mathrm{MtCu}^{2+} / \mathrm{PLA}$ and $\mathrm{MtCu}^{0} / \mathrm{PLA}$ nanocomposites against E.coli.

\begin{tabular}{|c|c|c|c|}
\hline \multirow{2}{*}{ Sample } & \multirow{2}{*}{ CFU/ml x 10 } & \multicolumn{2}{|c|}{ Reduction } \\
\cline { 3 - 4 } & & $\begin{array}{c}\text { Log (CFU/ } \\
\text { ml) }\end{array}$ & (\%) \\
\hline & & & \\
\hline $1 \% \mathrm{MtCu}^{2+} / \mathrm{PLA}$ & $104.4 \pm 61,7$ & 3.68 & 99.97 \\
\hline $3 \% \mathrm{MtCu}^{2+} / \mathrm{PLA}$ & $1.17 \pm 0,24$ & 5.64 & 99.99 \\
\hline $5 \% \mathrm{MtCu}^{2+} / \mathrm{PLA}$ & $0.15 \pm 0,07$ & 5.75 & 99.99 \\
\hline \multicolumn{3}{|c|}{} \\
\hline $1 \% \mathrm{MtCu}^{0} / \mathrm{PLA}$ & $17500 \pm 3536$ & 1.46 & 96,53 \\
\hline $3 \% \mathrm{MtCu}^{0} / \mathrm{PLA}$ & $8670 \pm 141$ & 1.76 & 98.28 \\
\hline $5 \% \mathrm{MtCu}^{0} / \mathrm{PLA}$ & $0.20 \pm 0,14$ & 5.63 & 99.99 \\
\hline
\end{tabular}

Values are presented as mean $\pm \mathrm{SD}$ of three replicates.

Table 5. Antimicrobial activity of $\mathrm{MtCu}^{2+} / \mathrm{PLA}$ and $\mathrm{MtCu}^{0} / \mathrm{PLA}$ nanocomposites against $L$. Innocua.

\begin{tabular}{|c|c|c|c|}
\hline \multirow{2}{*}{ Sample } & \multirow{2}{*}{ CFU/ml x 10 } & \multicolumn{2}{|c|}{ Reduction } \\
\cline { 3 - 4 } & & $\begin{array}{c}\text { Log }(\mathbf{C F U} / \\
\mathbf{m l})\end{array}$ & $\mathbf{( \% )}$ \\
\hline & & & \\
\hline $1 \% \mathrm{MtCu}^{2+} / \mathrm{PLA}$ & $19333 \pm 9238$ & 1.10 & 92.13 \\
\hline $3 \% \mathrm{MtCu}^{2+} / \mathrm{PLA}$ & $14889 \pm 4073$ & 1.22 & 93.94 \\
\hline $5 \% \mathrm{MtCu}^{2+} / \mathrm{PLA}$ & $298 \pm 181$ & 2.92 & 99.88 \\
\hline \multicolumn{3}{|c|}{} \\
\hline $1 \% \mathrm{MtCu}^{\circ} / \mathrm{PLA}$ & $72889 \pm 6167$ & 0.53 & 70.32 \\
\hline $3 \% \mathrm{MtCu}^{\circ} / \mathrm{PLA}$ & $245,0 \pm 35.4$ & 3.00 & 99.90 \\
\hline $5 \% \mathrm{MtCu}^{\circ} / \mathrm{PLA}$ & $0.40 \pm 0.14$ & 5.79 & 99.99 \\
\hline
\end{tabular}

Values are presented as mean $\pm \mathrm{SD}$ of three replicates.

\section{CONCLUSIONS}

It was possible to obtain $\mathrm{MtCu}^{2+} / \mathrm{PLA}$ y $\mathrm{MtCu}^{0} / \mathrm{PLA}$ nanocomposites films by casting technique. The study of the structural properties showed that both modified clays are intercalated in the polymer matrix due to increased interlayer space evidenced by DRX. TEM micrographs evidenced tactoids structures and presence of free copper nanoparticles when $\mathrm{MtCu}^{0}$ was used.
Thermal properties showed that the crystalline fraction decreases with increasing $\mathrm{MtCu}^{2+}$ and increases with increasing $\mathrm{MtCu}^{0}$ in the PLA. On the other hand an increase of the modulus of elasticity for $\mathrm{MtCu}^{2+} / \mathrm{PLA}$ and $\mathrm{MtCu}^{0} /$ PLA nanocomposites, obtaining a more rigid material. Therefore, it was possible to observe an increase in color variation and opacity by incorporating the modified clays in the polymer matrix.

Finally, it was possible to obtain a maximum of $5.75 \mathrm{log}$ reductions against E. coli to films with $5 \%$ of $\mathrm{MtCu}^{2+}$. While the largest antimicrobial activity against $L$. innocua was working with $5 \% \mathrm{MtCu}^{0} / \mathrm{PLA}$ nanocomposite film obtaining a $5.79 \log$ reduction and $5.79 \log$ reduction against $L$. Innocua to films with $5 \%$ of $\mathrm{MtCu}^{2+}$.

\section{ACKNOWLEDGEMENTS}

The authors are grateful to the Fondo Nacional de Desarrollo Científico y Tecnológico (Project FONDECYT de Iniciación 11110518).

The authors are also grateful for support from the Comisión Nacional de Investigación Científica y Tecnológica, CONICYT, for financial support from the Programa Bicentenario de Ciencia y Tecnología (Project PDA-22) and the Programa de Financiamiento Basal para Centros Científicos y Tecnológicos de Excelencia (Project FB0807).

\section{REFERENCES}

1.- $\quad$ K. Galic, M. Scetar, M. Kurek, Trends Food Sci Tech 22, 127, (2011).

2.- K. Marsh, B. Bugusu, J Food Sci 72, R39, (2007).

3.- V. Siracusa, P. Rocculi, S. Romani, M. Dalla Rosa, Trends Food Sci Tech 19, 634, (2008).

4.- C. Silvestre, D. Duraccio, S. Cimmino, Prog Polym Sci 36, 1766, (2011).

5.- J. Sarasa, J. M. Gracia, C. Javierre, Bioresource Technol 100, 3764, (2009).

6.- A. Azzi, D. Battini, A. Persona, F. Sgarbossa, Packag Technol Sci 25, 435, (2012).

7.- M. Cannarsi, A. Baiano, R. Marino, M. Sinigaglia, M. A. Del Nobile, Meat Sci 70, 259, (2005).

8.- F. Rodriguez, H. M. Sepulveda, J. Bruna, A. Guarda, M. J. Galotto, Packag Technol Sci 26, 149, (2013).

9.- K. Khwaldia, C. Perez, S. Banon, S. Desobry, J. Hardy, Crit Rev Food Sci 44, 239, (2004).

10.- N. Cao, Y. H. Fu, J. H. He, Food Hydrocolloid 21, 1153, (2007).

11.- N. E. Suyatma, A. Copinet, L. Tighzert, V. Coma, J Polym Environ 12, 1, (2004).

12.- M. A. Huneault, H. B. Li, Polymer 48, 270, (2007).

13.- V. Katiyar et al., Journal of Applied Polymer Science 122, 112, (2011).

14.- M. D. Sanchez-Garcia, A. Lopez-Rubio, J. M. Lagaron, Trends Food Sci Tech 21, 528, (2010).

15.- E. Fortunati et al., Polymer Degradation and Stability 97, 2027, (2012).

16.- H. Balakrishnan, A. Hassan, M. U. Wahit, A. A. Yussuf, S. B. A. Razak, Mater Design 31, 3289, (2010).

17.- M. Jamshidian, E. A. Tehrany, M. Imran, M. Jacquot, S. Desobry, Compr Rev Food Sci F 9, 552, (2010).

18.- E. Fortunati et al., Journal of Applied Polymer Science 124, 87, (2012).

19.- A. Arora, G. W. Padua, J Food Sci 75, R43, (2010).

20.- H. M. C. de Azeredo, Food Res Int 42, 1240, (2009).

21.- J. Weiss, P. Takhistov, D. J. McClements, J Food Sci 71, R107, (2006).

22.- D. R. Paul, L. M. Robeson, Polymer 49, 3187, (2008).

23.- D. S. Tong, H. S. Xia, C. H. Zhou, Chinese Journal of Catalysis 30, 1170, (2009)

24.- P. M. S. Souza, A. R. Morales, M. A. Marin-Morales, L. H. I. Mei, J Polym Environ 21, 738, (2013).

25.- T. V. Duncan, Journal of Colloid and Interface Science 363, 1, (2011).

26.- E. L. Bradley, L. Castle, Q. Chaudhry, Trends Food Sci Tech 22, 604, (2011).

27.- D. Dainelli, N. Gontard, D. Spyropoulos, E. Zondervan-van den Beukend, P. Tobbacke, Trends Food Sci Tech 19, S103, (2008).

28.- P. Suppakul, J. Miltz, K. Sonneveld, S. W. Bigger, J Food Sci 68, 408, (2003).

29.- A. Llorens, E. Lloret, P. A. Picouet, R. Trbojevich, A. Fernandez, Trends Food Sci Tech 24, 19, (2012).

30.- G. J. Brewer, Chem Res Toxicol 23, 319, (2010).

31.- H. T. Michels, J. O. Noyce, C. W. Keevil, Lett Appl Microbiol 49, 191, (2009).

32.- G. Grass, C. Rensing, M. Solioz, Appl Environ Microb 77, 1541, (2011). 
33.- M. Raffi et al., Ann Microbiol 60, 75, (2010).

34.- G. G. Ren et al., Int J Antimicrob Ag 33, 587, (2009).

35.- Y. J. Lee, S. Kim, S. H. Park, H. Park, Y. D. Huh, Materials Letters 65, 818, (2011).

36.- D. Longano et al., Analytical and Bioanalytical Chemistry 403, 1179, (2012).

37.- S. A. Wilks, H. T. MichelS, C. W. Keevil, International Journal of Food Microbiology 111, 93, (2006).

38.- G. Faundez, M. Troncoso, P. Navarrete, G. Figueroa, Bmc Microbiology 4, (2004).

39.- S. Mehtar, I. Wiid, S. D. Todorov, Journal of Hospital Infection 68, 45, (2008).

40.- L. J. Wheeldon et al., Journal of Antimicrobial Chemotherapy 62, 522 , (2008).

41.- L. Weaver, H. T. Michels, C. W. Keevil, Lett Appl Microbiol 50, 18 , (2010).

42.- D. Quaranta et al., Appl Environ Microb 77, 416, (2011).

43.- A. Ammalaa et al., Progress inPolymerScience 36, 1015, (2011).

44.- J. E. Bruna, A. Peñaloza, A. Guarda, F. Rodríguez, M. J. Galotto, Applied Clay Science $\mathbf{5 8}$ 79, (2012).

45.- P. Praus, M. Turicova, M. Klementova, J Brazil Chem Soc 20, 1351 , (2009)

46.- J. W. Rhim, S. I. Hong, C. S. Ha, Lwt-Food Sci Technol 42, 612, (2009).
47.- R. I. Quintero, F. Rodriguez, J. Bruna, A. Guarda, M. J. Galotto, Packag Technol Sci DOI: 10.1002/pts.1981, (2012).

48.- C. D. Papaspyrides, S. Pavlidou, Prog Polym Sci 33, 1119, (2008).

49.- J. Ahmed, J. X. Zhang, Z. Song, S. K. Varshney, Journal of Thermal Analysis and Calorimetry 95, 957, (2009).

50.- M. Ataeefard, S. Moradian, Appl Surf Sci 257, 2320, (2011).

51.- M. Labaki, J. F. Lamonier, S. Siffert, A. Aboukais, Thermochimica Acta 427, 193, (2005).

52.- J. H. Chang, Y. U. An, D. H. Cho, E. P. Giannelis, Polymer 44, 3715, (2003).

53.- G. Ozkoc, S. Kemaloglu, Journal of Applied Polymer Science 114, 2481, (2009).

54.- S. Y. Lee, H. Chen, M. A. Hanna, Ind Crop Prod 28, 95, (2008).

55.- P. Bordes, E. Pollet, L. Averous, Prog Polym Sci 34, 125, (2009).

56.- L. Zaidi, M. Kaci, S. Bruzaud, A. Bourmaud, Y. Grohens, Polymer Degradation and Stability 95, 1751, (2010).

57.- D. Battegazzore, S. Bocchini, A. Frache, Express Polym Lett 5, 849 , (2011).

58.- L. Jiang, J. W. Zhang, M. P. Wolcott, Polymer 48, 7632, (2007).

59.- G. Das, R. D. Kalita, P. Gogoi, A. K. Buragohain, N. Karak, Applied Clay Science 90, 18, (2014).

60.- L. Nan et al., J Mater Sci Technol 24, 197, (2008).

61.- M. Valodkar et al., J Hazard Mater 201, 244, (2012). 